\section{STUDENTS' PERCEPTION ON THE USE OF RUANGGURU APPLICATION IN THEIR ENGLISH LEARNING}

\author{
Aulia Fatimannisa', Syarifuddin Dollah², Amirullah \\ Abduh $^{3}$ \\ Universitas Negeri Makassar
}

Email: hj.geminastitisakkir@yahoo.com

Abstrak. Penelitian ini bertujuan untuk mengetahui Persepsi siswa terhadap penggunaan aplikasi Ruangguru dalam pembelajaran Bahasa Inggris mereka. Peneliti menerapkan metode campuran (kuantitatif dan kualitatif). Populasi dari penelitian ini adalah siswa kelas dua SMA Islam Athirah Makassar pada tahun akademik 2019/2020. Sampel yang diambil terdiri dari 24 siswa ya ng diambil dengan menggunakan teknik simple random sampling. Data yang diperoleh melalui kuesioner dianalisis dan ditabulasi berdasarkan klasifikasi persepsi menggunakan skala likert dan data dari wawancara dianalisis dengan merekam dan menyalinnya. Hasil analisis data menunjukkan bahwa (1) persepsi siswa positif terhadap penggunaan aplikasi Ruangguru dalam pembelajaran bahasa Inggris mereka dengan skor rata-rata 70 (2) berdasarkan klasifikasi siswa bahwa $5(20.8 \%)$ siswa diklasifikasikan sebagai Sangat positif, $10(41.7 \%)$ siswa diklasifikasikan sebagai Positif, 5 (20.8\%) siswa diklasifikasikan sebagai Sedang, 3 (12.5\%) siswa diklasifikasikan sebagai Negatif dan 1 (4.5\%) siswa diklasifikasikan sebagai Sangat negatif. Ini menunjukkan bahwa sebagian besar siswa suka menggunakan Ruangguru dalam pembelajaran bahasa Inggris.

Kata Kunci: Persepsi Siswa, Aplikasi Ruangguru, Pembelajaran Bahasa Inggris
INTERFERENCE

Journal of Language,

Literature, and

Linguistics

\section{E-ISSN: 2721-1835 \\ P-ISSN: 2721-1827}

Submitted: July $5^{\text {th }}, 2020$

Accepted : August $10^{\text {th }}, 2020$

Abstract. This study aimed at finding out the Students' Perception on the Use of Ruangguru Application in Their English Learning. The researcher applied mixed method (quantitative and qualitative). The population of this research was the second grade students of Senior High School of Athirah Islamic School Makassar in 2019/2020 academic year. The sample was taken consisted of 24 students which were taken by using simple random sampling technique. The data were obtained through the questionnaire were analysed and tabulated based on the classification of perception using Likert scale and the data from interview were analysed by recording and transcribing it. The results of data analysis showed that (1) students' perception was positive on the use of Ruangguru application in their English learning by mean score 70 (2) based on the students' classification that 5 (20.8\%) students classified as Strongly positive, 10 (41.7\%) students classified as Positive, 5 (20.8\%) students classified as Moderate, 3 (12.5\%) students classified as Negative and 1 (4.5\%) students classified as Strongly negative. This was indicated that most students like using Ruangguru in their English learning. 


\section{INTRODUCTION}

English is an international language that is used as a language of communication between all nations and countries around the world. The ability to speak English is one of the abilities that is very important for students because English has become a universal language used in the world of technology, politics, commerce, and the most important thing in the field of education. Nishanti (2018) stated that English is one of the most used and dominating languages in the world and this is having its impact on every field of work. In accordance with the Indonesian curriculum, English is one of the most important subjects so we hope that students already have good skills in this regard. But in fact, students' English proficiency is still low average and not as expected because they think English lessons are difficult to learn. According to John \& Ehow (2011), stated that the problems of learning English language derived from many different factors in different environments such as school resources, class size, quality of teachers, and the school attendance of learners. To overcome these cases students can take the initiative to study or online course through E-learning media (Sakkir, 2020).

One of the most recently established and popular E-learning media is Ruangguru. Ruangguru is the largest and most comprehensive technology company in Indonesia focusing on education-based services. It is an online self- learning platform with topic-based journeys consisting of animated videos, quizzes, Infographic summaries, and topic exercises accessible through Ruangguru application (https://ruangguru.com/general/about).

Based on the learning features available through the Ruangguru application as well as the various conveniences offered, are they comparable to the satisfaction of students who have subscribed to the Ruangguru application? Therefore, the researcher is inspired to conduct a research about students' perception on the use of Ruangguru application in their English learning.

\section{Perception}

According to Robbins and Judge (2013), perception is a process by which individuals organize and interpret their sensory impressions in order to give meaning to their environment. According to Gibson (1979), perception is bottomup (influenced by environment stimuli) and direct. Perception results from sensation initially derived from the optic array, which picks up consistent information from the environment and does so even when there is interaction with different aspects of the environment (Sakkir \& Abrar 2018).

\section{E-Learning}

According to Soekartawi (2003), e-learning is a generic term for all technologically supported learning using an array of teaching and learning tools as phone bridging, audio, and videotapes, teleconferencing, satellite transmissions, and the more recognized web-based training or computer aided instruction also commonly refers to as online courses. Moreover e-Learning is one type of teaching and learning that delivers teaching material to students using the internet, internet or other computer network media (Hartley, 2001; Sakkir \& Dollah, 2019). 


\section{Ruangguru Application}

PT. Ruang Raya Indonesia known as Ruangguru is one of the marketplaces in the field of education in Indonesia. A technology-based education service provider and content company founded in April 2014 by Adamas Belva Devera and Muhammad Iman Usman. Ruangguru is a forum that connects students with teachers. Where students can find teachers based on their needs and vice versa, teachers can deliver their knowledge. Teaching and learning activities facilitated by Ruangguru provide a learning management system that can be used by students and teachers in managing learning activities in a virtual classroom. This application equipped with thousands of question banks whose content is adjusted to the curriculum prevailing in Indonesia and test results analysis equipment where users can use it free of charge.

\section{RESEARCH METHOD}

In order to achieve the research question, the research design which is accordance with this research was mix method. Mix method approach is selected as the research design by combining qualitative and quantitative data collection procedures with two main reasons. Firstly, Creswell (2009) states mixed method utilizes the strength of both qualitative and quantitative research. Secondly, Hamied (2017) states that the research will get better understanding when combining both qualitative and quantitative data.

In this research, the total samples are 30 students from second grade of Senior High School of Athirah Islamic School Makassar. In order to get sample, the researcher used simple random sampling technique. The researcher chooses simple random sampling technique because the population was homogeny based on the process of learning by using Ruangguru Application. According to Ary et al (2010) simple random sampling is a sampling technique in which all members of the population have an equal and independent chance to be selected as a sample.

In order to collect data, the researcher applied two instruments. They are questionnaire and interview. Both instruments were used to obtain the depth and rational data and answer the research questions in the problem statement.

\section{FINDINGS AND DISCUSSION}

\section{Findings}

The following The findings of the research show the result of the questionnaire and interview to answer the research questions in the first chapter. The research question is "What is the students' perception on the use of Ruangguru Application in their English learning?" The researchers collected data through questionnaires and interviews.

There are twenty four (24) students of second grade in Senior High School of Athirah Islamic School Makassar taken as respondents in this research. Based on the data analysis from the questionnaire, it was found that students' perception on the use of Ruangguru application in their English learning is positive. It can be seen from the result of mean score in the questionnaire that was calculated as below: 


$$
\bar{X}=\frac{\Sigma X}{N}=\frac{1689}{24}=70
$$

The total score from questionnaire was 1689 with the total sampling was 24. It shows that the mean score of the students' perception on the use of Ruangguru application in their English learning is 70 which means it is included in the positive classification. The result of the mean score was supported by frequency and the percentage of the questionnaire which showed on the diagram.

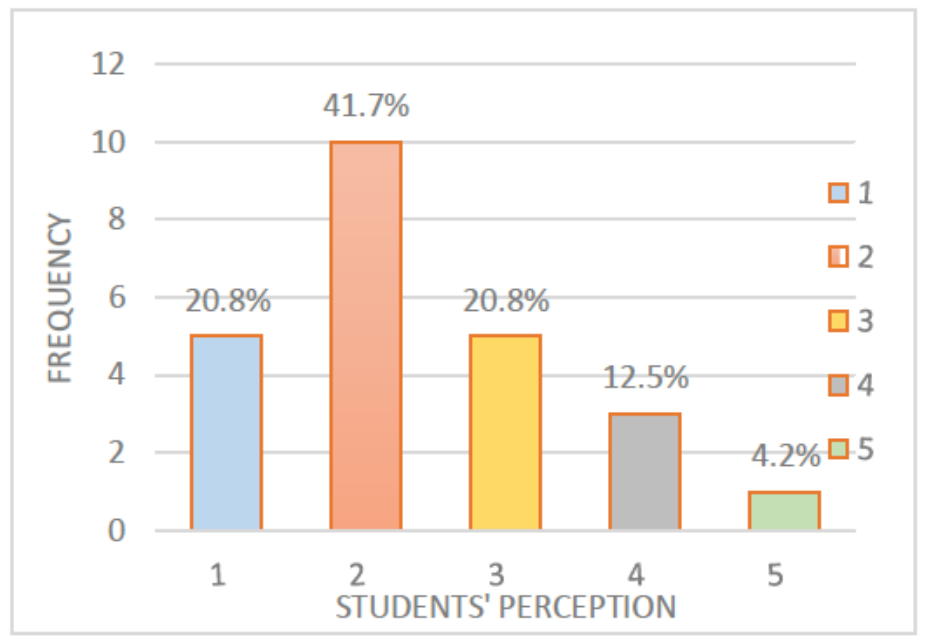

Relating to the result of students' perception, it shows that there are several explanations that expressed a, positive, moderate, and negative view. It can be concluded as follow:

\section{Positive Perception}

There are 5 (20.8\%) students have strongly positive and 10 (41.7\%) students have positive perception. It can be concluded that 15 (62.5\%) students have positive perception on the use of Ruangguru application in their English learning, this is proven by the results of interviews with students who also expressed their agreement to the use of Ruangguru as seen below.

Extarct 1

(Student 1, 30/06/2020/No.2)

...karna di Ruangguru sangat bagus, mulai dari materinya dan kita lebih memahami pelajarannya. (because Ruangguruu is excellent, starting from the material and we can more understand the material).

\section{Moderate}

There are $5(20.8 \%)$ students have moderate perception or response. It was supported by the result of interview as follows:

Extarct 1

(Student 3, 30/06/2020/No.4) 
... lengkapji iya kak (materi) tapi begitumi susah karna virtual. (the material is quite complete but it's rather difficult because it's virtual).

\section{Negative}

There are $3(12.5 \%)$ students have negative and $1(4.2 \%)$ student have strongly negative perception. It can be concluded that 4 (15\%) students have negative e perception on the use of Ruangguru application in their English learning, it was supported by the result of interview as follows:

Extarct 1

(Student 3, 30/06/2020/No.5)

... masalah biayanyaji kak karna kan ini biayanya Ruangguru bisa dibilang agak mahal. (payment problems because it can be said that the fee of Ruangguru are rather expensive).

\section{Discussion}

Regarding to result of the data from findings which showed that the students had positive perception, it could not be separated from advantages of Ruangguru application itself. Based on the data from findings, some comments from the students said that Ruangguru application is a good online learning platform. The researcher can concluded that it was happened because Ruangguru have a best features, presents material in different forms, users will get animated videos and Infographic, and the user can learn flexibly, anywhere, and anytime. It was relevant with Tjokro (2009) e-learning has many advantages such as more easily to be absorbed, it means to use multimedia facilities in the form of images, text, animation, sound, and video. It's also related to the previous study in Shofie et al (2019) stated that the features in Ruangguru application had a positive satisfaction to the user of Ruangguru application.

In other side, how to the tutors teach was a another indicators that students having positive perception of Ruangguru application. Based on student responses, overall answers explained that tutor in Ruangguru was pleasant. The explanation from the tutor is easy to understand and this also makes students believe that learning at Ruangguru application can increase the score of their English subject. Besides that from the explanation of students, their score in English can increase because the material in Ruangguru application is in accordance with the Indonesian curriculum in the school. It was related from the theory of Chapter II about the advantages of Ruangguru application stated that the material provided by Ruangguru is in accordance with curriculum standards in Indonesia. Thus, the material must have good quality. This quality learning material can be obtained equally and evenly by every user accessing online tutoring through the application, in contrast to conventional tutoring, where subject matter can be missed or poorly conveyed due to instructor factors and the location of the tutoring. As stated previously, the researcher concluded that there are several factors which influenced 
the students' perception, whether is positive or negative perception. It was related to the theory by Sobur (2003) stated that there are two factors that affecting perception, they are internal factors and external factors.

The advantages and disadvantages are one of the factors that influenced whether their perception was positive or negative. Thus, researcher indicated that there are still students had negative response or perception. Ruangguru as a ELearning does not always provide the best side because it was designed for students and tutors in teaching and learning process which certainly has advantages and disadvantages. It was related to the theory by Sujana (2005) stated that the advantages of e-learning is to provide flexibility, interactivity, speed, visualization through the various advantages of each media and L. Gavirlova (2006) stated that the disadvantages of e-learning is requiring additional equipment such as computer, monitor, keyboard, etc.

Based on the consideration from discussion, the researcher concluded that there are several factors which make Ruangguru application in English learning have positive response. Firstly, the features that Ruangguru provides are interesting. In this application, the students would get animated videos and Infographic so learning can be more fun. Secondly, how the tutor teaches is fun. Thirdly, learning in Ruangguru application can increase their score of English in school because the material provided by Ruangguru is based on the Indonesian curriculum.

\section{CONCLUSION}

Based on the findings and discussion of the previous chapter, the researcher concludes that:

1. The students' perception on the use of Ruangguru application in their English learning is positive. It was proven by the result of the students' rating mean score which was 70. It was supported from percentage of the questionnaire which showed that $5(20.8 \%)$ students classified as strongly positive, 10 (41.7\%) students classified as positive, $5(20.8 \%)$ students classified as moderate, 3 (12.5\%) students classified as a negative and 1 (4.2\%) student classified strongly negative. It could be interpreted that the students' had positive perception about Ruangguru application in English learning.

2. The students' explanation on interview about the perception of Ruangguru explained that Ruangguru is good and interesting online learning platform has a best fitures especially for learning English has a good tutors and Ruangguru can increase their English score in the school.

\section{REFERENCES}

Ary, D., Jacobs, L. C., \& Sorense, C. (2010). Introduction to research in education eigth edition. Belmont: Wadsworth.

Creswell, John .W. (2009). Research Design: Pendekatan Kualitatif, Kuantitatif, dan 


\section{Education.}

Gibson, J. (1979). The ecological approach to visual perception. Boston: Houghton Hamied, F.A. (2017). Research method : a guid for first-time researchers. Bandudng: UPI Press.

Hartley. (2001). Selling E-Learning. New York: Association for Talent Development.

John, L., \& Ehow, C. (2011). Factors affecting quality of english language teaching. Journal of Trend in Scientific Research and Development, 3(1), 871-874. Jurnal Teknodik, 3-5.

L. Gavirlova, M. (2006). Computational science and its applications-ICCSA. Glaskow: Springer.

L. Tjokro, S. (2009). Presentasi yang mencekam. Jakarta: Elex Media Komputindo.

Nishanti, R. (2018). The importance of learning english in today world. International

Robbins, S. J. (2013). Organizational behavior Edition 15. New Jersey: Pearson

Sakkir, G. (2016). Interest and Writing Skill of the University Students on Using Social Media-Facebook in Writing Class (STKIP Muhammadiyah Rappang, Indonesia). In Asian EFL Journal (Second Language Acquisition- Academic Research) TESOL Indonesia International Conference Edition (Vol. 2, pp. 178-188).

Sakkir, G. (2018). Writing: Beginner. Deepublish.

Sakkir, G. (2020). The Effectiveness of Pictures In Enhance Writing Skill of Senior High School Students. Interference: Journal of Language, Literature, and Linguistics, 1(1).

Sakkir, G., \& Abrar, A. E. Y. (2018). "Students' Perception of the Implementation Facebook Group in Learning Writing Skill." In PROCEEDINGS OF THE 65th TEFLIN INTERNATIONAL CONFERENCE, vol. 65, no. 02. 2018.

Sakkir, G., \& Dollah, S. (2019). FACEBOOK-BASED WRITING INSTRUCTIONAL MATERIAL IN ENGLISH CLASS: LECTURERS'PERCEPTION. SELTICS, 2(2), 7683.

Sakkir, G., \& Dollah, S. (2019). Measuring students'writing skills using Facebook group application in EFL context. International Journal of Humanities and Innovation (IJHI), 2(3), 69-72. https://doi.org/10.33750/ijhi.v2i3.43

Shofi, S., Rachmadi, A., \& Herlambang, A. (2019). Analisis Kebutuhan Pengguna Aplikasi Ruangguru Menggunakan Metode Fuzzy Kano. Jurnal Pengembangan Teknologi Informasi Dan Ilmu Komputer, 3(5), 4307-4315. Diambil dari http://j-ptiik.ub.ac.id/index.php/j-ptiik/article/view/5189.

Sobur, A. (2003). Psikologi Umum. Bandung: Pustaka Setia.

Soekartawi. (2003). Prinsip dasar e-learning: Teori dan aplikasinya di Indonesia.

Sujana. (2005). Metode statistika. Bandung: Tarsito. 